\title{
フラーレンナノウィスカーの合成と性質
}

\author{
宮 澤 薰 一 \\ 独立行政法人 物質・材料研究機構 桥305-0044＼cjkstart茨城県つくば市並木 1-1 \\ （2006 年 9 月 1 日受理）
}

\section{Synthesis and Properties of Fullerene Nanowhiskers}

\author{
Kun'ichi MiYAZAWA \\ National Institute for Materials Science \\ 1-1 Namiki, Tsukuba, Ibaraki 305-0044
}

(Received September 1, 2006)

\begin{abstract}
Since the discovery of $\mathrm{C}_{60}$ nanowhiskers in 2001 , fullerene nanowhiskers with various morphologies and compositions have been synthesized, and mechanical, thermal, electrical and magnetic properties of $\mathrm{C}_{60}$ nanowhiskers have been investigated. This paper reviews the recent research progress in the synthesis of fullerene nanowhiskers and characterization of their properties.
\end{abstract}

\section{1. は じめに}

フラーレンナノウィスカー（fullerene nanowhisker, FNW）とは， $\mathrm{C}_{60}$ や $\mathrm{C}_{70}$ などのフラーレン分子からなる 細いひげ結晶（ウィスカー）のことである。結晶質, 非 晶質に限らず，フラーレン分子からなるナノ繊維を，一 般にフラーレンナノファイバー (fullerene nanofiber, FNF) と呼んでいる1)。ファイバーとは, 長さに対する直径の 比（アスペクト比）が， 3 以上の粒子として定義されて いる2)。

フラーレンナノウィスカーには, 中空でないものと, 中空なものとの 2 種類があり, 後述の液-液界面析出法 によって合成することができる。中空なフラーレンナノ ウィスカーをフラーレンナノチューブ (fullerene nanotube, FNT）と称するが，特に断らずにフラーレンナノ ウィスカーというときは, フラーレン分子から成る中空 でないひげ結晶のことを指す。フラーレンとしては, $\mathrm{C}_{60}$ や $\mathrm{C}_{70}$ などの他に, 原子内包フラーレンや, 置換基で修 飾されたフラーレン分子の全てが対象である。C 60 のマ ロン酸エステル誘導体 $\mathrm{C}_{60}\left[\mathrm{C}\left(\mathrm{COOC}_{2} \mathrm{H}_{5}\right)_{2}\right]$ のみからなる FNW も合成した ${ }^{3)}$ 。

FNW の研究は, $\mathrm{C}_{60}$ を少量添加したチタン酸ジルコ ン酸鉛（PZT）のコロイド溶液中に $\mathrm{C}_{60}$ ナノウィスカー

E-mail: MIYAZAWA.Kunichi@nims.go.jp
を発見したときから始まった4)。

FNT の合成は, $\mathrm{C}_{60}$ の白金誘導体を少量含む $\mathrm{C}_{60}$ 粉末 を用いて得られた $\mathrm{C}_{60}$ ナノチューブ $\left(\mathrm{C}_{60} \mathrm{NT}\right)$ が最初で ある5，6)。その後，ピリジンをフラーレンの溶媒に用い て, $\mathrm{C}_{70}$ ナノチューブ $\left(\mathrm{C}_{70} \mathrm{NT}\right)$ と $\mathrm{C}_{70}$ を約 $15 \mathrm{~mol} \%$ 含 む $\mathrm{C}_{60} \mathrm{NT}$ の合成7)，および， $\mathrm{C}_{60} \mathrm{NT}$ の合成に成功した ${ }^{8)}$ 。 本稿ではこれまでに合成された FNW の種類と構造, 物性, 応用の試みについて述べる。

\section{2. フラーレンナノウィスカーの合成方法}

FNW は, 液一液界面析出法（液-液界面法, 液-液法, liquid-liquid interfacial precipitation method, LLIP 法) によ って，常温で合成することができる ${ }^{9 \sim 11)}$ 。液-液界面析 出法とは, トルエン, メタキシレン, ピリジンなどのフ ラーレンの良溶媒飽和溶液に, フラーレンの貧溶媒であ るアルコール（イソプロピルアルコール（IPA），イソ ブチルアルコールなど）を加えて液-液界面を形成し, FNW の析出と成長を行わせる方法である。

液-液法による FNW の合成は, ガラスビンにフラー レンの上記飽和溶液を入れ，その上にアルコールを重層 して, 約 $20^{\circ} \mathrm{C}$ 以下の冷所に静置することによって行う ことができる。

中空な FNW である FNT の場合は, フラーレンのピ リジン飽和溶液をガラスビンに入れ, IPAをピリジン溶 液の数倍量以上注いで, 液-液法面を作り, 冷所に置く 


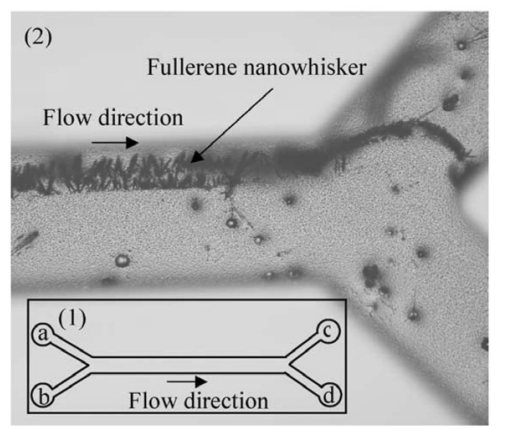

Fig. 1. Inset of the microchannel reactor (1) and optical micrograph of fullerene nanowhiskers synthesized using the microchannel reactor (2) (Reprinted from Carbon, Vol. 43, S.-H. Lee, K. Miyazawa and R. Maeda, $\mathrm{C}_{60}$ nanowhisker synthesis using a microchannel reactor, pp.887-889, Copyright (2005), with permission from Elsevier). ${ }^{14)}$

ことにより合成できる。液-液法面の形成時に, 超音波 を照射したり，手で振るなどして意図的に界面を乱すこ とにより，FNT の生成率を向上させた ${ }^{12) 。 こ の こ と は, ~}$ FNT の成長において, 核生成が重要な役割を果たして いることを示唆する。

$\mathrm{C}_{60} \mathrm{NT}$ の合成においては, 中心波長が $302 \mathrm{~nm}$ の紫外 線ランプによって照射することにより, 収率を向上させ ている12)。光照射下で, $\mathrm{C}_{60}$ とピリジン分子が反応して, ピリジン分子が $\mathrm{C}_{60}$ にいくつか付加した化合物ができる ことが報告されている13)。いくつかのピリジン分子が付 加した $\mathrm{C}_{60}$ が, チューブ状ファイバーを生じるための適 当な大きさになっていると推察される。

液一液法は，マイクロ流路を用いた合成プロセスに適 用できる。Fig. 1 は, Leeらによって, 作製されたマイ クロ流路による FNW の合成装置である ${ }^{14)}$ 。

この装置は，シリコン基板上に作製したマイクロチャ ンネル (幅 $250 \mu \mathrm{m}$, 深さ $123 \mu \mathrm{m}$, チャンネル長 $22.5 \mathrm{~mm}$ ) である。シリコン基板はパイレックスガラスで覆われて おり，ガラスの a, b, c, d の部分に孔が空いている。 液体の入り口は, $\mathrm{a}$ と $\mathrm{b}$, 出口は $\mathrm{c}$ とし, $\mathrm{d}$ は閉鎖され た。入り口 aにIPA を，入り口 bに $\mathrm{C}_{60}$ を飽和させた卜 ルエンを流し込むことにより，チャンネル部分で液-液 法面が形成されて， $\mathrm{C}_{60} \mathrm{NW}$ が界面に垂直に生成した。 このマイクロチャンネル法は FNW を連続合成するのに 適している。最近, Shinoharaらも, 同様にして, 中空 の針状晶を含む多様な形状の $\mathrm{C}_{60}$ 結晶を合成した ${ }^{15}$ 。

\section{3. フラーレンナノウィスカーの構造}

Fig. 2 に, 液-液法で合成された $\mathrm{C}_{60} \mathrm{NT}$ （矢印）の走 查型電子顕微鏡二次電子像を示す。この $\mathrm{C}_{60} \mathrm{NT}$ の外径

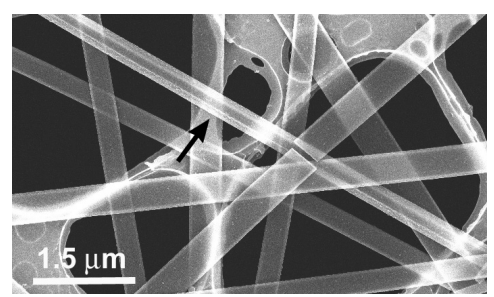

Fig. 2. SEM image of $\mathrm{C}_{60}$ nanotube (arrow).

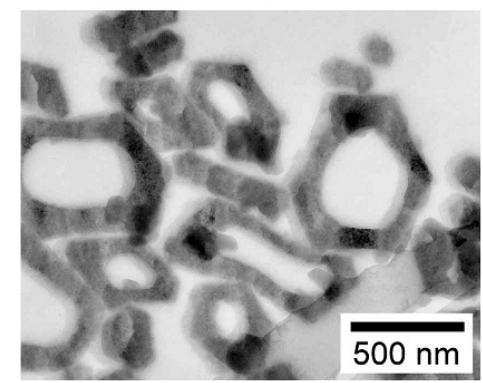

Fig. 3. Cross-sectional TEM image of $\mathrm{C}_{60}$ nanotubes. ${ }^{16)}$

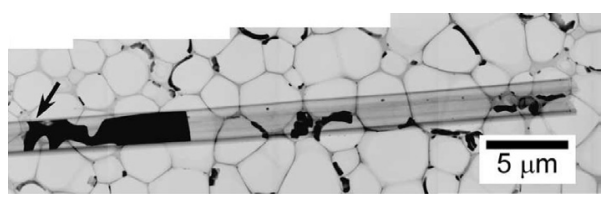

Fig. 4. TEM image for $\mathrm{KBr}$ crystals (arrow) deposited into a C60 tube. ${ }^{17)}$

は約 $320 \mathrm{~nm}$, 内径は約 $110 \mathrm{~nm}$ で，およそ $105 \mathrm{~nm}$ の壁 厚を持っている. Fig. 3 の透過電子顕微鏡（TEM）によ る断面像に示すように, $\mathrm{C}_{60} \mathrm{NT}$ の内径は, 数十 $\mathrm{nm}$ から 数百 $\mathrm{nm}$ である。

また， $\mathrm{C}_{60} \mathrm{NT}$ の壁の外表面と内表面は，10 nm オーダ 一の厚さの変質層で覆われている。この $\mathrm{C}_{60} \mathrm{NT}$ の中に は，毛管現象によってアルコールが吸引されるので，物 質を溶解させたアルコールを流し込み, アルコールを蒸 発除去することにより，目的とする物質を充填させるこ とができる17)。また， $\mathrm{C}_{60}$ のチューブ壁を有機溶媒で溶 解し去り, 内部の物質を回収することも可能である ${ }^{17) 。}$ 溶解させた $\mathrm{C}_{60}$ は再利用することができる。Fig. 4 は, $\mathrm{KBr}$ のメチルアルコール溶液を, 太めの $\mathrm{C}_{60}$ チューブに 吸入させて得た $\mathrm{KBr}$ 固体 (矢印) を示している。また,

Fig. 5 は, チューブ壁を溶解後, 回収した $\mathrm{KBr}$ 結晶の光

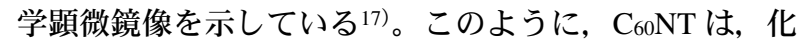
学合成の可除去テンプレートとして利用することができ る。

Fig. 5 でO印をつけた KBr ナノウィスカーの直径は, 


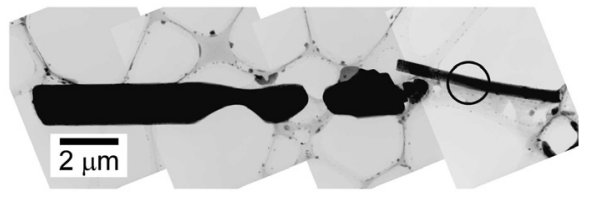

Fig. 5. TEM image for $\mathrm{KBr}$ crystals extracted from $\mathrm{C}_{60}$ tubes. ${ }^{17)}$

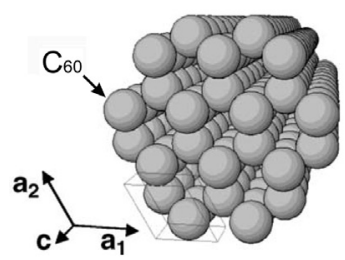

Fig. 6. Model for a part of $\mathrm{C}_{60}$ nanotube wall with a hexagonal structure (Reprinted from Diamond \& Related Materials, Vol. 15, J. Minato and K. Miyazawa, Structural characterization of $\mathrm{C}_{60}$ nanowhiskers and $\mathrm{C}_{60}$ nanotubes fabricated by the liquid-liquid interfacial precipitation method, pp. 1151-1154, Copyright (2006), with permission from Elsevier). ${ }^{8)}$

約 $410 \mathrm{~nm}$ である。

液-液法で合成した $\mathrm{C}_{70} \mathrm{NT}$ の平均壁厚は約 $113 \mathrm{~nm}^{7)}$, $\mathrm{C}_{60} \mathrm{NT}$ の壁厚は約 $71 \mathrm{~nm}$ であった ${ }^{17)}$ 。フラーレンの分子 種によって異なった壁厚のナノチューブが生じることが わかる。

合成したての $\mathrm{C}_{70} \mathrm{NT}$ は, 六方晶(格子定数 $\mathrm{a}=1.603 \mathrm{~nm}$, $\mathrm{c}=1.09 \mathrm{~nm}$ ）の溶媒和構造をとることがわかった ${ }^{8)}$ 。溶 媒和した $\mathrm{C}_{60} \mathrm{NT}$ は, $\mathrm{C}_{70} \mathrm{NT}$ と同様の $\mathrm{X}$ 線回折図形を示 し, 六方晶（格子定数 $\mathrm{a}=1.541 \mathrm{~nm}, \mathrm{c}=1.00 \mathrm{~nm}$ ）と求 められた ${ }^{8)}$ 。C $60 \mathrm{NT}, \mathrm{C}_{70} \mathrm{NT}$ ともに, チューブの成長軸 と $\mathrm{c}$ 軸とが平行となっている。Fig. 3 の $\mathrm{C}_{60 \mathrm{NT}}$ の断面像 は, $\mathrm{c}$ 軸に垂直な切断面を示している。純粋の $\mathrm{C}_{60}$ は, 常温常圧では面心立方晶（FCC，格子定数 $\mathrm{a}=1.417 \mathrm{~nm}$ ） であり ${ }^{18)}, \mathrm{C}_{60}$ の最隣接分子間距離は $1.00 \mathrm{~nm}$ である。 このように，溶媒和した構造では， $\mathrm{C}_{60}$ 分子がチューブ 軸に沿って最密充填している。 $\mathrm{C}_{70} \mathrm{NT}$ においても， $\mathrm{C}_{70}$ 分子がチューブ軸方向に最密充填している。

Fig. 6 は, 溶媒和した $\mathrm{C}_{60} \mathrm{NT}$ 壁の六方晶構造モデルで ある (空間群 $\left.\mathrm{P} 6_{3} / \mathrm{mmc}^{8}\right)$ )。メタキシレン/IPA の系で合 成した, 中空でない $\mathrm{C}_{60} \mathrm{NW}$ の壁の結晶構造は, 六方晶 （格子定数 $\mathrm{a}=2.405 \mathrm{~nm}, \mathrm{c}=1.001 \mathrm{~nm}$ ）であった ${ }^{19) 。}$

Fig. 6 に示すように, $\mathrm{C}_{60} \mathrm{NT}$ の壁は c 軸方向に沿って, 直径約 $0.8 \mathrm{~nm}$ のチャンネルを持っている。このチャン ネルは溶媒分子を取り込むのに十分な大きさである。

$\mathrm{C}_{60} \mathrm{NW}$ の六方晶構造は，Fig. 7 に示すものを考えてい る (空間群 $\left.\mathrm{P}_{3}\right)_{3}{ }^{19)}$ 。ウィスカーの成長軸方向 $(/ / \mathrm{c}$ 軸方

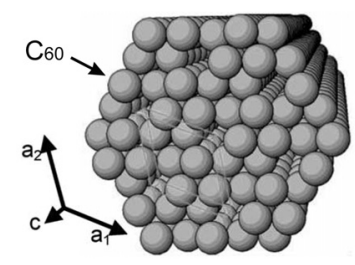

Fig. 7. Model for a part of $\mathrm{C}_{60}$ nanowhisker with a hexagonal structure (Reprinted from Carbon, Vol. 43, J. Minato and K. Miyazawa, Solvated structure of $\mathrm{C}_{60}$ nanowhiskers, pp. 2837-2841, Copyright (2005), with permission from Elsevier). ${ }^{19)}$

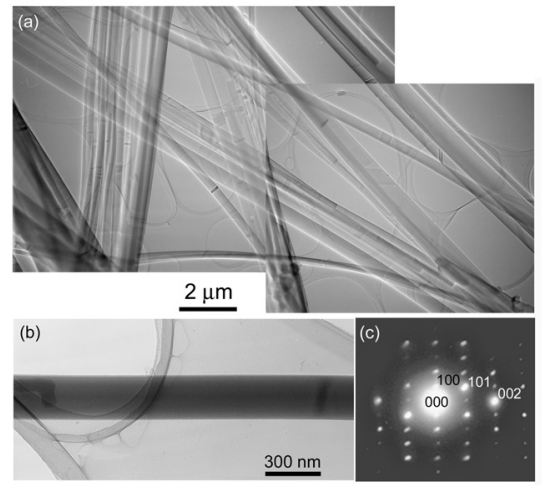

Fig. 8. (a)TEM image for $\mathrm{C}_{60}$ nanowhiskers with a composition of $\mathrm{C}_{60}-4.2 \mathrm{~mol}_{0} \mathrm{C}_{60}\left[\mathrm{C}\left(\mathrm{COOC}_{2} \mathrm{H}_{5}\right)_{2}\right]$ and (c) SAEDP indexed by a hexagonal system for the nanowhisker (b). ${ }^{20)}$

向）に沿って， $\mathrm{C}_{60}$ 分子が最密充填しており, c 軸方向 に沿うチャンネルに溶媒分子を取り込むことができる。

上記のように，溶媒和した $\mathrm{C}_{60} \mathrm{NT}$ と $\mathrm{C}_{60} \mathrm{NW}$ は，とも に六方晶であり， $\mathrm{C}_{60}$ 分子が， $\mathrm{c}$ 軸の長さに等しい中心 間距離 $1.0 \mathrm{~nm}$ で, 成長軸方向に最密に充填しているが, $\mathrm{a}$ 軸の長さと空間群が異なっている。

$\mathrm{C}_{60}$ 分子結晶 $(\mathrm{FCC})$ の $\mathrm{X}$ 線密度は, $1.68 \mathrm{gcm}^{-3}$ であ る。また，溶媒を除いた $\mathrm{C}_{60}$ のみから成る六方晶 $\mathrm{C}_{60} \mathrm{NW}$ の $\mathrm{X}$ 線密度は $1.43 \mathrm{gcm}^{-3}$, 六方晶 $\mathrm{C}_{60} \mathrm{NT}$ 壁の $\mathrm{X}$ 線密度 は $1.16 \mathrm{gcm}^{-3}$ と計算される。溶媒除去後においても溶 媒和構造が安定であると仮定すると, 六方晶 $\mathrm{C}_{6} \mathrm{NW}$ は, $\mathrm{FCC}$ 構造のものに比べて軽く, 六方晶 $\mathrm{C}_{60} \mathrm{NT}$ の壁の密 度はさらに小さく, 六方晶構造を安定にさせる研究は興 味深いテーマである。 $\mathrm{C}_{60} \mathrm{NT}$ と $\mathrm{C}_{60} \mathrm{NW}$ の構造は異なる ので，異なった物性を示すことが期待される。

合成したての $\mathrm{C}_{60} \mathrm{NW}$ の六方晶構造は, 乾燥によって 溶媒を失うと FCC 構造に変化するが，適当な置換基を 持つ $\mathrm{C}_{60}$ 誘導体を添加することにより安定化されること を見出した ${ }^{20)}$ 。

Fig. 8 は, $\mathrm{C}_{60}$ のマロン酸エステル誘導体 $\mathrm{C}_{60}[\mathrm{C}$ $\left.\left(\mathrm{COOC}_{2} \mathrm{H}_{5}\right)_{2}\right]$ を添加した $\mathrm{C}_{60}$ 飽和トルエン/IPA の系に 

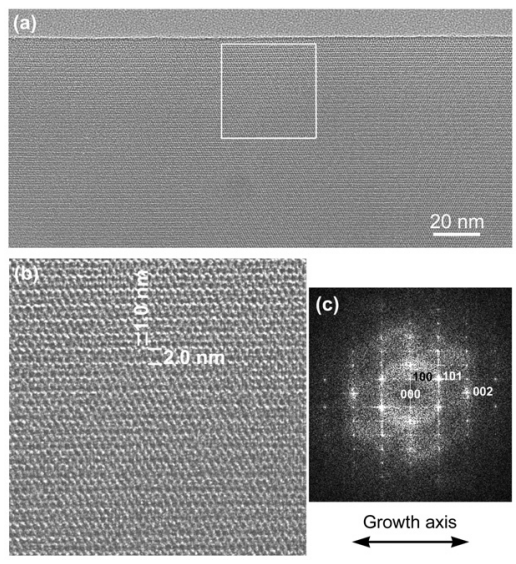

Fig. 9. (a) HRTEM image, (b) enlarged image for the area shown by the rectangle of photo (a), and (c) FFT pattern for photo (b) in a $\mathrm{C}_{60}-4.2 \mathrm{~mol}_{\%} \mathrm{C}_{60}\left[\mathrm{C}\left(\mathrm{COOC}_{2}\right.\right.$ $\left.\mathrm{H}_{5}\right)_{2}$ ] nanowhisker. ${ }^{20)}$

おいて合成した $\mathrm{C}_{60} \mathrm{NW}$ の TEM 写真である。図（b）の $\mathrm{C}_{60} \mathrm{NW}$ に対する制限視野電子線回折図形（SAEDP） (c) は, $\mathrm{a}=2.373 \pm 0.031 \mathrm{~nm}, \mathrm{c}=1.006 \pm 0.005 \mathrm{~nm}$ の六方晶 構造として指数付けされた ${ }^{20)}$ 。トルエン/IPA の系を用 いて合成した $\mathrm{C}_{60} \mathrm{NW}$ の SAEDP は成長軸に平行に高密 度に導入された面欠陥を示す回折斑点のストリークを生 じたのに対し9, 21), Fig.8の SAEDP（c）にはストリー クが観られない。これは, $\mathrm{C}_{60}\left[\mathrm{C}\left(\mathrm{COOC}_{2} \mathrm{H}_{5}\right)_{2}\right]$ の固溶に よって六方晶が安定化されたことにより, 六方晶 $\rightarrow \mathrm{FCC}$ 相変態に伴う面欠陥の導入が阻止されたためと推察して いる。

Fig. 9 (a) に示すように, $\mathrm{C}_{60}\left[\mathrm{C}\left(\mathrm{COOC}_{2} \mathrm{H}_{5}\right)_{2}\right]$ が固溶 した $\mathrm{C}_{60} \mathrm{NW}$ の表面は原子レベルで平坦であること, Fig. 9 （b）に示すように， $\mathrm{C}_{60}$ ケージが， $1.0 \mathrm{~nm}$ の間隔で成 長軸方向に沿って整然と並んでいる様子がわかる。

また, $\mathrm{C}_{60}$ (2-methoxycarbonyl-N-methylpyrrolidine) ${ }_{2}$ や $\mathrm{C}_{60}$ （2-methoxycarbonyl-Nmethylpyrrolidine）を添加した $\mathrm{C}_{60}$ 粉末を用いた場合も，六方晶構造が安定化された ${ }^{20)}$ 。

\section{4. フラーレンナノウィスカーの物性}

Fig. 10 は，TEM 中での $\mathrm{C}_{60} \mathrm{NW}$ の曲げ試験の様子（筑 波大学木塚研究室）を示す22)。C 60 飽和トルエン/IPA の 系で合成した $\mathrm{C}_{60} \mathrm{NW}$ （直径約 $150 \mathrm{~nm}$ ）を, 複合型透過 電子顕微鏡中で, $\mathrm{Si}$ チップによって曲げ変形させた。C 60 $\mathrm{NW}$ は曲率半径 $4 \mu \mathrm{m}$ で破断することなく湾曲してい る。Fig. 10 の矢印はひずみによる等傾角干渉縞を示し ている。また, 同じ TEM 内において, $\mathrm{C}_{60} \mathrm{NW}$ (直径 170 $\mathrm{nm}$ ，長さ $3.5 \mu \mathrm{m} ）$ の一端を試料ホルダーに固定し他の 一端をピエゾ駆動の $\mathrm{Si}$ チップで押すことによって座屈 変形させ, その荷重-変位曲線から, $\mathrm{C}_{60} \mathrm{NW}$ のヤング率

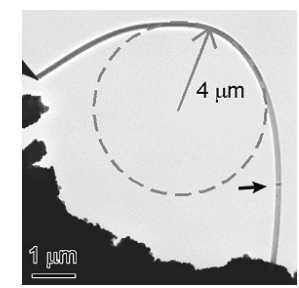

Fig. 10. Transmission electron microscopy image of a $\mathrm{C}_{60}$ nanowhisker bent by a Si tip. ${ }^{22)}$

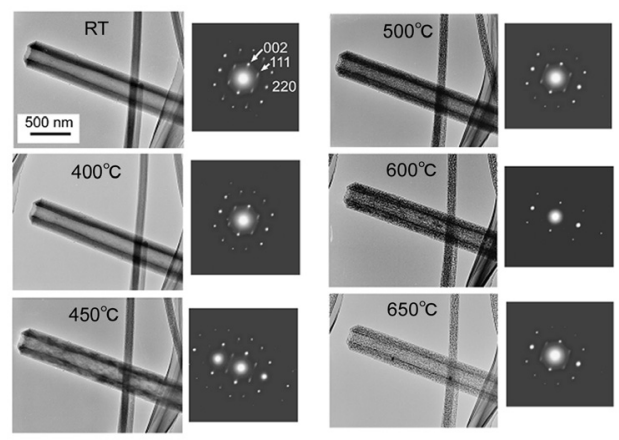

Fig. 11. In-situ heating experiment of $\mathrm{C}_{60}$ nanotube by TEM.

Eが $30 \mathrm{GPa}$ と求められた22)。これは, $\mathrm{C}_{60}$ 分子結晶のヤ

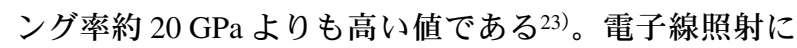
より $\mathrm{C}_{60}$ が重合する可能性があるので， $\mathrm{C}_{60} \mathrm{NW}$ の機械 的性質に対する電子線照射の影響も知る必要がある。

また, Asakaらは, 真空熱処理した $\mathrm{C}_{60} \mathrm{NW}$ を, TEM 中で通電加熱すると, 複数のグラフェン層からなる中空 ナノカーボンが生成すること, しかも，これが可視領域 で強く発光することを発見した ${ }^{24)}$ 。

$\mathrm{C}_{60} \mathrm{NT}$ の TEM (JEM-2010 E，200 kV) 中におけるその 場加熱実験を行った様子を Fig. 11 に示す。表示温度は 加熱ホルダーの温度である。 $450^{\circ} \mathrm{C}$ 以上の温度で $\mathrm{C}_{60} \mathrm{NT}$ 壁は多孔質となった ${ }^{12)}$ 。C $60 \mathrm{NT}$ の SAEDP は， $650^{\circ} \mathrm{C}$ ま で, 単結晶構造が維持されることを示している。他の TEM 中その場加熱観察例では, $\mathrm{C}_{60} \mathrm{NT}$ は, $750^{\circ} \mathrm{C}$ まで は結晶構造を維持した ${ }^{12)}$ 。

Fig. 12 は, Fig. 11 の $\mathrm{C}_{60} \mathrm{NT}$ の面間隔を, 加熱温度の 関数として示したものである。面間隔は室温から $650^{\circ} \mathrm{C}$ までの間で，ほぼ一定である。また，FCC 構造を仮定 した場合，Fig.12の（111），(002），(220）面間隔から 求められる格子定数は，それぞれ， $\mathrm{a}=1.43 \mathrm{~nm}, \mathrm{a}=1.57$ $\mathrm{nm}, \mathrm{a}=1.37 \mathrm{~nm}$ であるので, この $\mathrm{C}_{60} \mathrm{NT}$ は, $\mathrm{FCC}$ 構造 から歪んでいることがわかる。体心正方晶構造を仮定し て, 格子定数を, $\mathrm{a}=0.966 \mathrm{~nm}, \mathrm{c}=1.568 \mathrm{~nm}$ とすると, 上記の面間隔を説明できる。高圧合成によってポリマー 化した体心正方晶 $\mathrm{C}_{60}$ 結晶の格子定数としては, $\mathrm{a}=$ 


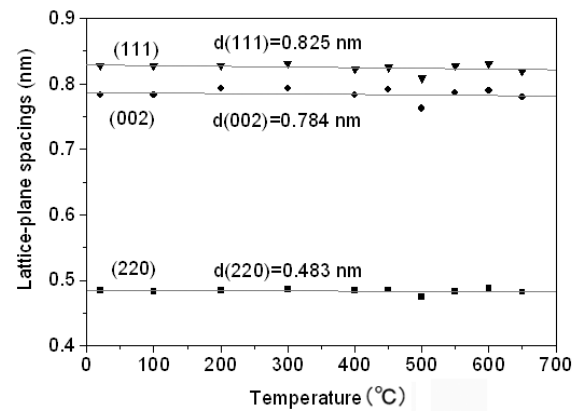

Fig. 12. Lattice plane spacings of the $\mathrm{C}_{60}$ nanotube heated in TEM (Fig. 11) as a function of heating temperature.

$0.909 \mathrm{~nm}, \mathrm{c}=1.495 \mathrm{~nm}$ の值が報告されている25)。

$\mathrm{C}_{60} \mathrm{NW}$ の電気伝導は, Ogawa らによって, 電界効果 トランジスタ（FET）を作製して調べられている26)。C60 メタキシレン飽和溶液/IPA の系で合成した $\mathrm{C}_{60} \mathrm{NW}$ は $0.3 \mu \mathrm{m}$ 末満の直径を持ち, 中には約 $20 \mathrm{~nm}$ の直径の細 い $\mathrm{C}_{60} \mathrm{NW}$ も観察された。〜 $440 \mathrm{~K}, \sim 10^{-6}$ Torr で真空 熱処理により脱溶媒した $\mathrm{C}_{60} \mathrm{NW}$ は, FCC 構造 $(\mathrm{a}=1.39$ $\mathrm{nm}$ ）であり, ファン・デル・ワールス $\mathrm{C}_{60}$ 結晶（pristine $\left.\mathrm{C}_{60}\right)$ の格子定数 $(\mathrm{a}=1.417 \mathrm{~nm})^{18)}$ よりも小さかった。 我々も, $\mathrm{C}_{60} \mathrm{NW}$ の成長軸方向における $\mathrm{C}_{60}$ 分子間距離 が pristine $\mathrm{C}_{60}$ のものに比べて約 $4 \%$ 縮小していること を見出し, $\mathrm{C}_{60} \mathrm{NW}$ が成長軸方向にポリマー化している ことを仮定した9)。真空熱処理した $\mathrm{C}_{60} \mathrm{NW}$ で作製した FET の特性から， $\mathrm{C}_{60} \mathrm{NW}$ のキャリヤー移動度が $2 \times 10^{-2}$ $\mathrm{cm}^{2} / \mathrm{Vs}$ と求められた ${ }^{26)}$ 。

朴らは, $10 \mathrm{~T}$ の超伝導マグネットを用いて, 室温で, ポリビニルアルコール中に分散させた $\mathrm{C}_{60} \mathrm{NW}$ と $\mathrm{C}_{60} \mathrm{NT}$ の強磁場中での配向実験を行い， $\mathrm{C}_{60} \mathrm{NW}$ は磁場に平行 に配向するが， $\mathrm{C}_{60} \mathrm{NT}$ は磁場に垂直に配向することを見 出した27)。配向の違いが, ウィスカーの形状の違いによ るのか, 結晶構造の違いによるのかを明らかにすること は興味深い課題となっている。

\section{5. ま と め}

$\mathrm{C}_{60} \mathrm{NW}$ の発見から 5 年間が経過した。この間, FNW を合成する液-液界面析出法は, マイクロチャンネルに も適用できる普遍性の高い方法であることが実証され た。また，中空な FNW も中空でない FNW も合成でき ることが発見され, 多様な FNW が合成できることが示 された。また, $\mathrm{C}_{60} \mathrm{NW}$ の力学的, 電気的, 熱的, 磁気 的性質も明らかにされつつある。

FNW には，合成に用いる溶媒の違いによって，結晶 構造の異なるものが生じることや，同一溶媒の組合せに おいても, 中空なウィスカーと中空でないウィスカーの
両方を生じる場合があることがわかっている。FNW が 中空な構造になるメカニズムについては，FNW の表面 が溶解しにくい構造となっており, 溶媒和した内部フラ ーレンが溶出して中空構造が形成される機構を仮定して いる7)。しかし，その詳細については，今後の解明が必 要である。

\section{謝 辞}

本研究の一部は, 科学研究費補助金(課題番号 17201027）の支援により行われた。本研究にご協力いた だいた共同研究者各位に篤く御礼申し上げます。

\section{文献}

1) 宮澤薰一 : フラーレンのナノウィスカーとナノファ イバー : “ナノファイバーテクノロジーを用いた高 度産業発掘戦略” (シーエムシー出版, 2004) p. 103.

2) Nanoscience and nanotechnologies: opportunities and uncertainties (The Royal Society \& The Royal Academy of Engineering, 2003, http://www.nanotec.org.uk/finalReport.htm) p. 37.

3) K. Miyazawa, T. Mashino and T. Suga: J. Mater. Res. 18, 2730 (2003).

4) K. Miyazawa, A. Obayashi and M. Kuwabara: J. Am. Ceram. Soc. 84, 3037 (2001).

5) K. Miyazawa and T. Suga: J. Mater. Res. 19, 3145 (2004).

6）宮澤薰一, 須賀唯知：公開特許広報 特開 2005-306706 (2005).

7) K. Miyazawa, J. Minato, T. Yoshii, M. Fujino and T. Suga: J. Mater. Res. 20, 688 (2005).

8) J. Minato and K. Miyazawa: Diamond \& Related Materials 15, 1151 (2006).

9) K. Miyazawa, Y. Kuwasaki, A . Obayashi and M. Kuwabara: J. Mater. Res. 17, 83 (2002).

10) K. Miyazawa and M. Kuwabara : 米国特許 US 6890505 B 2 (2005).

11) 宮澤薰一，桑原 誠：特許第 3785454 号 (2006).

12) K. Miyazawa, J. Minato, M. Fujino and T. Suga: Diamond \& Related Materials 15, 1143 (2006).

13) J. Cheng, Y. Fang, Q. Huang, Y. Yan and X. Li: Chem. Phys. Lett. 330, 262 (2000).

14) S.H. Lee, K. Miyazawa and R. Maeda: Carbon 43, 887 (2005).

15) K. Shinohara, T. Fukui, H. Abe, N. Sekimura and K. Okamoto: Langmuir 22, 6477 (2006).

16) 湊 淳一, 宮澤薰一：日本物理学会講演概要集 61 , (2006) p. 815.

17) J. Minato and K. Miyazawa: J. Mater. Res. 21, 529 (2006).

18) D. McCready and M. Alnajjar: Powder Diffraction File No. 44-558, International Centre for Diffraction Data, Newton Square, PA (1994).

19) J. Minato and K. Miyazawa: Carbon 43, 2837 (2005).

20) K. Miyazawa, J. Minato, T. Mashino, S. Nakamura, M. 
Fujino and T. Suga: NUKLEONIKA 51 Supplement 1, S 41 (2006).

21) K. Miyazawa, K. Hamamoto, S. Nagata and T. Suga: J. Mater. Res. 18, 1096 (2003).

22) 宮澤薰一, 湊 淳一, 加藤良栄, 安坂幸師, 木塚徳

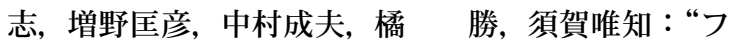
ラーレンナノウィスカー・フラーレンナノチューブ の常温合成と物性”, フィジカルセンサ研究会資料, (社) 電気学会, 東京大学生産技術研究所 (2006).

23) S. Hoen, N.G. Chopra, X.-D. Xiang, R. Mostovoy, J. Hou, W.A. Vareka and A. Zettl: Phys. Rev. B 46, 12737 (1992).

24) K. Asaka, R. Kato, Y. Maezono, R. Yoshizaki, K. Miyazawa and T. Kizuka: Appl. Phys. Lett. 88, 051914-1
(2006).

25) M. Núñez-Regueiro, L. Marques, J.-L. Hodeau, O. Béthoux and M. Perroux: Phys. Rev. Lett. 74, 278 (1995).

26) K. Ogawa, T. Kato, A. Ikegami, H. Tsuji, N. Aoki, Y. Ochiai and J.P. Bird: Appl. Phys. Lett. 88, 112109 (2006).

27）朴 光哲，木村史子，木村恒久，宮澤薰一，湊 淳 一, 石塚 (生沼) みどり, 土屋敬広, 若原孝次, 赤 阪 健：“フラーレンナノウィスカーの磁場配向挙 動”, 電気学会 E 準部門 ユビキタス社会のための ナノマテリアル・プロセス技術調査専門委員会 FNW 研究会 合同研究会 講演資料集, (独) 物質 材料研究機構, つくば (2006) p. 6. 